\title{
POLITICAL INFLUENCES ON TEACHER EDUCATION IN NEW ZEALAND
}

\author{
BARBARA HAROLD \\ Department of Professional Studies \\ University of Waikato
}

\begin{abstract}
Over the last decade the New Zealand education system has undergone dramatic administrative and curricular reforms. The last serious scrutiny of teacher education was in 1985, but the current focus on reform in the tertiary sector, combined with a crisis in teacher supply, has brought renewed attention to the issue. The government's current Green Paper 'Quality Teachers for Quality Learning' is provoking widespread debate about the principles and practices of teacher education. This paper outlines and critically discusses key elements of the government's proposals for reform, and highlights some future policy issues for teacher education.
\end{abstract}

\section{INTRODUCTION}

Education policy in New Zealand has changed dramatically during the last decade as the principles of neo-liberalism and free market ideology have been increasingly applied to educational institutions. Prior to the 1980s, while education policy was officially the responsibility of Cabinet, it was for the most part influenced by successive Directors General of Education, and by the education community itself (McLaren, 1974). The election of the 1984 Labour government brought with it a much more direct ministerial involvement in policy implementation than had previously been seen (Halverson, 1996; Snook 1997). In education, this was evident during Labour's second term when the incumbent Prime Minister also took on the education portfolio, signalling a serious focus on change. Although the government changed in 1990, subsequent education ministers have continued to have extensive powers. For example, the minister can sack poorly performing boards of trustees (the governing body of each school) and appoint commissioners to govern schools in their place, and has the power of veto over membership of curriculum and policy development groups.

Between 1987 and 1996 education reform was primarily focussed on the compulsory sector of education - primary and secondary schooling. The first wave of reform dramatically changed the administration of schools, and was followed in 1991 by the introduction of significant curricular reforms which are still continuing today.

The reforms have repositioned schools to align them more closely with the principles and practices of the free-market as established by Friedman (1962). Key elements of this ideology include "user pays", a market-style competition between schools, freedom of choice for "consumers" such as parents and students, supply and demand, and providers and purchasers.

While serious doubts have arisen about the validity of these principles in the field of education (Bell 1998; Codd, 1997) policy makers have not been persuaded 
to modify their approach. The application of these principles to teacher education raises further concerns for those involved in the field.

This paper will describe the political decisions which have impacted on teacher education in the late 1990s, provide an analysis of the effects of these decisions and suggest some future issues for teacher education.

\section{NEW POLICY DEVELOPMENTS}

Teacher education largely escaped attention during the first period of reforms but two factors have recently brought it into sharp focus. The first of these was the crisis in teacher supply which became obvious during the mid-nineties. Sullivan (1997:252) outlines three elements which resulted in a critical shortage of teachers at this time:

1. swelling of student numbers to schools, and a lack of anticipation of this by government ;

2. dropping off of enrolments in teacher training programmes; and

3. larger than normal exodus of teachers from the profession (c.f. Wyllie, 1997)

The teacher supply crisis has already resulted in direct government intervention to raise the number of new recruits to the profession.

The second factor is concerned with the final wave of reform where attention has been focussed on the tertiary sector of education. Two Green Papers were introduced simultaneously by the Ministry of Education to signal proposals for the reform of the tertiary sector in general and teacher education in particular. The second of these, entitled Quality Teachers For Quality Learning: A Review of Teacher Education (Ministry of Education, 1997) clearly indicated the influence of market ideology on pre- and in-service preparation of teachers.

Concerns arising from the above factors cover a wide perspective. Some are related to macropolitical issues such as the impact of new right ideology and control of the educational process. Others involve micropolitical issues such as the impact of new policies on teachers' working lives, and the nature of the profession.

\section{THE TEACHER SUPPLY CRISIS}

Direct government intervention in the teacher education process was evident in 1995 and 1996 as a politically embarrassing teacher shortage became apparent. At this time, five Colleges of Education, one university School of Education, and one very small private institution were responsible for the preparation of all teachers for the state system. Most primary pre-service programmes were of three or four years duration, and those for secondary teaching were either concurrent degree/diploma programmes of 4 or 5 years, or graduate programmes of 1 year. The state pre-service institutions had wide-ranging autonomy in course content, but this was mediated to a degree by the profession, through representation on programme committees and through the New Zealand Council for Teacher Education. 
Impelled by the teacher supply crisis, the government moved quickly to introduce short term measures which it hoped would reduce the problem including the introduction of compressed graduate programmes for primary teachers, retraining programmes for teachers who had left the system, and the importation of teachers from overseas.

\section{Compressed graduate courses for primary teachers}

These programmes had some significant differences to then current pre-service teacher education programmes. Funding was based on a contestable pool, open to both state and private institutions. Interested providers had to submit a programme which, if approved by the Teacher Registration Board (TRB), was implemented as a contract between the institution and the Ministry of Education, with a requirement for programme evaluation.

\section{Retraining programmes}

Since 1995, the Ministry of Education has offered contracts to state education providers to recruit previously qualified teachers from the community pool, and bring them up to date with current school practice. At my own institution, for example, several hundred such recruits have undergone an eight-week programme of this kind since 1995.

\section{Overseas teachers}

Since 1995, approximately 1100 teachers, the majority of whom are in the early stages of their careers, have been brought into the New Zealand system, predominantly from Canada, Australia, and the United Kingdom. The Teacher Registration Board and the New Zealand Qualifications Authority (NZQA) are responsible for checking qualifications and providing authorisation to teach. Most of the early wave of teachers have been employed in the primary sector, and currently there is a stronger focus on recruiting overseas teachers for the secondary sector, especially in the "hard to fill" subject areas such as maths and science, and to cater for roll growth as more primary age children move into the secondary sector.

\section{THE REVIEW OF TEACHER EDUCATION}

The second major area where government policy will influence teacher education is the review of teacher education (Ministry of Education, 1997). It is technically separate from, but part of, a larger tertiary sector review which will result in the implementation of the final phase of educational reform. Its key proposals are as follows:

The establishment of a professional body which would aim at allowing teachers to operate more like other professional groups. It would be responsible for the setting, maintenance and review of professional standards, teacher registration, and the provision of information to the government on strategic issues for teaching. 
Nationally agreed professional standards for teachers to be used for both registration, renewal of practicing certificates at different points of a teacher's career, and the development of specific performance-related criteria.

Resourcing pre-service teacher education which is likely to be linked to other tertiary funding. Pre-service education for Maaori-medium teachers will be specifically addressed. The current system of Normal and Model schools is likely to be disestablished. These kinds of schools are located close to traditional State teacher education providers and staff receive a special allowance for continuous involvement in pre-service programmes.

A pre-registration/induction period requiring greater school accountability for the mandatory 0.2 staffing entitlement during the first year of the two year period of induction for beginning teachers. Boards of trustees must provide professional support programmes for staff with limited authority to teach. (This term refers to staff who have not completed a programme of teacher education, but who may be approved by the TRB to be appointed for short term periods to provide particular expertise or skills such as Maaori language, or computer graphics).

Resourcing in-service teacher education by devolving responsibility for decisions about professional development, through directly funding schools.

\section{CONTESTATION AND RESISTANCE}

Although the reform of education has progressed inexorably through the last decade, it has been accompanied by negotiation, contestation, resistance and sometimes direct conflict (Harold, 1995).

Since the early 1990s the government itself has been supplied with an ongoing stream of policy advice from the Treasury and politically right wing groups such as the Business Roundtable (BRT) and the Education Forum (the education "arm" of the BRT). Snook (1997) notes that since 1991 the BRT has commissioned a large number of reports on aspects of government reform ranging from agriculture to education and their influence has been implicit in several policy decisions. He goes on to comment that, interestingly, a report on initial (pre-service) teacher education commissioned by the Education Forum in 1992 concluded that the system was in good shape. As those findings did not lend support to the views of the Forum, it was never made public and a further report (Partington, 1997) was commissioned. While admitting that his 'sample' of respondents was small, Partington (1997) was widely critical of what he saw as a monopoly held by established teacher education providers, and ideological capture' of pre-service course content. Key recommendations were for teacher education to be opened up to competition from both state and private providers; for greater flexibility in entry requirements; more "substantive" knowledge in programme content; and greater variety of school involvement in pre-service education.

No analysis of New Zealand policy development is complete without a consideration of the role of the teacher unions, the New Zealand Educational Institute (NZEI) for primary, and the Post Primary Teachers Association (PPTA) for secondary teachers. Coverage is over 90 percent in both sectors and the education unions are among the few remaining groups to maintain this level of 
membership following the introduction of draconian new labour regulations under the Employment Contracts Act (1990).

Prior to the start of reforms union groups were closely involved with policy making. McLaren (1974:32) commented for example that teacher organisations were so closely involved with the shaping of educational policy that "it [was] sometimes said that the New Zealand education system [was] one run by the teachers for the teachers". All this was to change after 1989, and nowhere was it more obvious than the exclusion of union groups from the planning of reform because of their "vested interests" (Snook, 1997).

The union voice has proved a key site of resistance to aspects of reform policy in the last decade, particularly the introduction of direct resourcing for teachers' salaries at the individual school level. Negotiation, contestation, and occasionally, direct conflict between the Ministry of Education and the unions has characterised policy development and implementation. It is rather ironic that in the first year of the reforms, during the confusion and uncertainty following the demise of the regional education boards, along with their institutional knowledge, that the unions (representing employees) played an important part in advising novice boards of trustees (employers) about key aspects of educational administration.

In the area of teacher education the impact of the teacher unions has been less clear. They were opposed to short term moves to ease the teacher supply problem, arguing that compressed courses and the importation of overseas teachers would, in the long term, threaten the quality of education. More recently, the PPTA has sought to introduce discussion of aspects of teacher preparation and supply into employment contract negotiations, arguing that supply and conditions are inextricably interwoven. The government has resisted this, taking the view that supply matters are its responsibility, actually arguing that negotiations are about pay only - the implication being that unions have no right to a say in matters of supply.

The teacher unions themselves have been faced with some tensions in attempting to reconcile their industrial role as a union with the professional role that they had developed in the decades prior to the reforms. There have also been occasional public differences of opinion between the teacher unions which, in some cases, the government has used to further its own position.

Teacher educators and other academics have also added to the debate about policy, but although they raise important questions (e.g. Jesson, 1997; Ramsay 1998; Snook, 1996; Sullivan, 1997) their voices have not been enough to stem the impetus of market ideology within their own institutions.

\section{THE IMPACT ON TEACHER EDUCATION}

\section{The Macropolitical Level}

The debate about teacher education in New Zealand is part of a much broader ideological struggle over the structure and content of education as a whole, which has continued throughout the decade (e.g. Lauder, 1990; Snook, 1997). Government policy initiatives have moved education steadily from a 
monopolistic, cooperative system to one characterised by competition and market forces.

The rhetoric of Quality Teachers for Quality Learning is characteristically that of flexibility, diversity and choice, but in the haste to introduce these elements to improve teacher supply, some problems have arisen. In the early childhood sector, for example, one teacher education provider has gone out of business, leaving students out of pocket and with incomplete qualifications. The provision of a sound infrastructure (e.g, library, curriculum resources) to support programmes has not always been evident. Ramsay (1998: 4) noted that he "was unimpressed with the facilities and resources and especially library resources, in the newer providers of teacher education". A more recent example of the negative impact of market ideology has occurred in Dunedin, a city of some 100,000 people, where the College of Education and the University have offered competing teacher education programmes. Ramsay (1998) comments that the numbers of students will not be high enough to sustain both programmes so that one institution will 'fail'. From a purely economic point of view it is difficult to see how the duplication of resources needed for two teacher education programmes in a small city can possibly be an efficient or even sensible use of taxpayer funds.

The introduction of competition between public and private providers has resulted in changes dominated by fiscal concerns. There was little choice, for example, for current teacher education institutions when the notion of compressed programmes for graduates was proposed in 1996, as they would lose funding to competitors if they did not offer the programmes. A similar example of how the 'market' can have a negative effect on teacher education occurred recently when one institution introduced a three year Bachelor of Education degree, hoping to make itself more competitive. However, when the Ministry of Education agreed to award the same salaries to graduates of this degree as to 4-year graduates, all the other institutions were forced to drop their 4-year programmes and introduce a 3-year Bachelor of Teaching too. This, critics argued, resulted in a simultaneous reduction of standards, choice and diversity.

A detailed account of the recent effects of government policy on teacher supply is provided by Jesson (1997) who is concerned that government policy development has been haphazard and hasty. In her view (1997: 347) the government has espoused free market principles from the outset (e.g. by allowing individual Boards of Trustees to determine supply through employment practices), and was then forced to abandon these when they failed to cope with the supply crisis. Since then, she argues, their policy has become more interventionist. Ramsay (1998: 8) also comments on the irony of government intervention in the teacher education process, given its avowed adherence to free market principles:

... much of what was originally a coherent, carefully-constructed, and above all else a well-balanced programme, lies in ruins in New Zealand. The right has won an important victory and ... this victory has been won at the expense of the open market, which was ignored in the battle. Once again [it has been shown that] even the most rabid free marketeer will turn to State intervention in order to further their own ideological positions. 
A different perspective on intervention is put forward by McQueen (1996) who maintains that teacher supply and quality will always be a political issue in New Zealand and the government itself is part of the "market" and thus impacts on the creation or diminishing of demand. This of course is a dilemma facing any nation state where the purpose of education has elements of private benefit and public good. Governments have vested interests of their own in the education system, given its wider contribution to the socioeconomic systems of the state.

\section{The Micropolitical Level}

The changes to pre-service teacher education have raised a number of issues. Direct government intervention in this field is disturbing to teacher educators in that it has the potential to undermine institutional autonomy despite arguing for the market to prevail, and processes of quality control. This, together with changes to the delivery of in-service professional development impacts on the nature of the profession as a whole. For example, the Review proposal that boards of trustees could be responsible for the provision of professional development for staff with limited authority to teach could potentially bypass the usual qualification routes.

The concept of quality is central to the debate, and the definition of this term is by no means clearcut. Ramsay (1998: 7) is strongly critical of what he terms the "dumbing down" of teacher education, and warns that the loss of the liberal elements in shortened pre-service programmes could lead to the production of :

... teachers who are politically naive, with little or no knowledge of the structure of society, with little or no knowledge of the relationship between social class and educational performance, with a failure to understand the difference between indoctrination and education, with little knowledge of the history of education or even more importantly, race relations in this country, and who understand nothing about the important positioning of education in power and politics.

Kelly (1996) raises questions about the purpose of a focus on the concept of quality, and asks whether it will be used as an external mechanism for teacher accountability, or more appropriately for improvement of institutional policy and practice. In her view, the site-based development of indicators of quality is an important professional role best done by institutions themselves if they are to claim professional integrity.

It is probably too early yet to form a reliable opinion about the impact of the new initiatives to increase the teacher supply, but initial reports have given cautious support for some aspects of the programmes. Renwick and Gray's (1997) review of the compressed programmes for graduates indicated that the programmes were run by experienced and well qualified staff and that the majority of students were highly committed to teaching. Students on the programmes tended to be older and more reflective than younger student teachers. On the other hand, Renwick and Gray (1997) point out some negative aspects such as relative inflexibility of programmes due to time constraints, 
limited student choice and reduced opportunities to specialise, and the intensity of the workload.

In their discussion of the experiences of the Teacher Registration Board in reviewing the implementation of the compressed courses, Mansell, Renwick and Gray (1997: 11) were critical of the lack of provision for research to parallel the introduction of the new programme:

The story of this review of the initial implementation of the compressed teacher education programmes illustrates the dilemmas involved in establishing adequate evaluation procedures for a new government policy. Many of the obstacles arise from a lack of adequate long term planning when government policies are developed and implemented in a hurry. If we are serious about sustaining and enhancing the quality of teacher education in New Zealand, we must insist on suitable internal and external evaluation procedures of existing programmes as well as new programmes.

Mansell et al. (1997) go on to make four recommendations which could provide greater assurance that national standards are being met in the introduction of new programmes:

1. a clear definition of 'standards';

2. a research programme to evaluate the impact of new programmes in relation to national standards;

3. committed resources and time to adequately introduce and evaluate new programmes; and

4. a continuous monitoring and review process (internal and external).

The retraining programmes for formerly qualified teachers have drawn a considerable number of people back into the profession, but the trend is for these teachers to return to the local relief teacher pool or to take up part time positions. In this respect the initiative has certainly strengthened the relief teacher situation in some areas.

The recruitment of overseas teachers has been varied in its impact. Most of the first wave were placed in primary schools, many in low socioeconomic areas of Auckland city. Approximately two thirds of these recruits have renewed contracts and will continue work in the schools. Some initial problems arose from the implementation of this policy. For example, some South Auckland schools had large numbers of overseas recruits arrive at the beginning of the year and principals and staff faced extra workloads to familiarise the new teachers with New Zealand school policies and practices (although some Ministry funding was provided to assist principals). There were concerns that it might be inappropriate for teachers from other cultures, who were unfamiliar with specific equity and cultural aspects in the New Zealand curriculum, to teach Maaori and Pacific Island children. Some recruits were disappointed with their placement and conditions and left early. The recruitment of overseas teachers continues but the focus has changed from the primary to the secondary sector, especially in mathematics, science, and technology. 
Another area of concern is whether reforms to teacher education will affect the international standing of the profession, for the trend towards shorter programmes is counter to what is happening in many other countries. Moves toward a graduate profession however, are consistent with overseas trends, but not a three-year graduate.

The proposal in the review of teacher education to give a stronger emphasis to academic content in particular areas signals a response to specified needs such as literacy and bicultural development in the preparation of young people for an increasingly complex society. But it can also be viewed as a mechanism to promote content areas that reflect the techno-rational perspective of 'new right' ideology including mathematics, science and technology.

The concept of teacher quality is a contentious, multi-dimensional one which is central to the current policy debate. At issue is the question of who decides what counts as quality and how it will be developed and measured.

\section{TEACHER EDUCATION IN THE NEW MILLENNIUM: SOME ISSUES}

While the policy developments outlined in this paper are firmly situated in the specifics of the New Zealand system, it is useful to compare political influences on teacher education in New Zealand with those in some other western nations, because some broad similarities in policy content and development are apparent. Whitty, Barton, Miles, Whiting and Furlong (1997) for example, in a comparison of initial teacher education in England, Australia, and the United States, draw attention to the range of common policy strategies being pursued by their respective governments. They note that policies for teacher education reflect both a struggle over the nature and form of initial teacher education, and over the character of professionalism for teachers moving into the schools. The similar policy elements identified by Whitty et al (1997) include:

- increased focus on school-based training;

- emphasis on externally prescribed and standardised, behaviouristbased 'competencies' in pre-service education;

- growing emphasis on subject-based knowledge in the pre-service curriculum, particularly mathematics and science; and

- a focus on national standards for teacher licensing.

Each of the four elements of similarity described above fits readily into the proposed policy framework for teacher education in New Zealand

Whitty et al (1997) go further in their analysis to discuss how the similar timing for the introduction of such policies in education reflects wider similarities in recent social, political, and economic policies in modern industrialised nations. While some theorists (e.g. Ball, 1990) would argue that this reflects the educational equivalent of a move from Fordist perspectives of mass markets and mass production to post-Fordist concepts of niche markets and flexible specialisation, Whitty et al (1997) suggest that a more plausible explanation might lie in the focus (by individual nation states) on the development of a strong state and a free economy where, ironically, governments devolve administrative and operative responsibility on to individual institutions, while retaining a tight centralised 
control of funding and policy. Such an analysis would certainly be plausible in the New Zealand situation where, alongside specific and unique policy developments, the education reforms have been broadly characterised by greater centralised control, despite the rhetoric of devolution and self-management. There is support for this comparison in the comments of Dale and Robertson (1997:219) who note that "it makes little sense [in New Zealand] to talk about an education system [but rather] an aggregation of individual schools ...tightly controlled from the centre" [original italics].

Since the implementation of the reforms New Zealand schools have been directly funded for all aspects of their operation except teacher salaries, the latter having been strongly resisted by the majority of teachers and boards of trustees, because of an inequitable formula for its implementation, and concerns that funding levels could ultimately be capped by government. By the introduction of a different funding formula and the provision of a large sum of money in the 1998 national budget, the Minister of Education has provided an almost irresistible enticement for individual schools to take the next step to bulk funded teacher salaries. Jesson (1997) believes that the move to devolve responsibility for inservice teacher education, and in some cases, pre-service education, to individual schools in a fully bulk-funded scenario could lead to increased fragmentation and difficulty in maintaining national ideals and standards.

For New Zealand then the control of the teaching profession will continue to be contested for some time. A key issue is the nature of teachers' work and their professional status. Critics such as Ramsay (1998) and Jesson (1997) have both expressed concerns that current policy could lead to poorer quality teacher preparation. Jesson (1997:356), for example, contends that the following scenario could occur:

Teaching as a career faces the real possibility that it will become even more focussed on skills and training and less concerned with the ethics of the profession. Teacher education will become short-term vocational training rather than a research-based critical education for the start of a lifelong career. The majority of teacher education for primary and secondary will then occur through a one-year postgraduate certificate/diploma at a range of institutions rather than a properly considered education degree.

A further issue in the debate over policy is the place of research. The call by Mansell et al. (1997) for a clear research programme to accompany the new initiatives in teacher education is a timely and important one. There have been enough expressions of concern to warrant the further development of a data base on teacher education, as a foundation for sound policy development. Such models can be found elsewhere. In the United States, for example, the College of Education at the University of Washington, has just begun a major 5-year multistate project to investigate the impact of new policy on teachers' classroom programmes. That project, which is funded by the Federal Department of Education, will have an important ongoing role in the establishment of a national database, the development of case studies of best practice and the dissemination of 
information to national and state policy developers, as well as to teachers themselves.

What has become evident during the last decade of educational reform, in New Zealand and other countries is the low trust relationship between policy makers and those who are responsible for its implementation. Whitty et al. (1997) argue that this extends even wider to a low trust between society and its educators. They note that while there has always been a tension between the teaching profession's claim to autonomy and its requirement to be responsive to the needs of a variety of other groups in a democratic society, this tension has been heightened rather than diminished by recent policy trends.

...'local' definitions of professionalism exist at the periphery alongside a strong core definition of teacher professionalism based on a restricted notion of professionality, supported by technologies of control that include the specification of competencies, [and] government inspections. (Whitty et al., 1997: 17)

While there are distinct differences between different systems, the above comments nevertheless connect strongly with those of critics in the New Zealand context who have fears about the future of teacher education.

\section{CONCLUSION}

A close examination of actual and proposed policy development in New Zealand teacher education leaves one with an impression of haste, uncertainty, short-term expediency, and lack of theoretical support. Viewed in the context of international developments, and the ideological framework underlying educational reform, there is a logical consistency in these policies which continues the pathway towards autonomous, self-managing institutions. Even within that framework though, the government has shown a readiness to forsake its non-intervention stance when necessary, as in the teacher supply example.

Although new policy has been contested and resisted, competition, shrinking tertiary funding and its related fiscal constraints have left little choice for teacher educators in the implementation of that policy.

One important avenue has been left open in the Review - the establishment of a body with oversight of all aspects of the profession. There has been cautious support for this initiative, but until the Review submissions are examined, its shape and role remain uncertain. In the interim, teacher educators and others in the profession are already moving towards the professional/regulatory body model themselves. The New Zealand Council of Teacher Education has recently disbanded due to its small membership and will likely be reconstituted in some new way. At the final conference of the NZCTE in October, 1998 the development of some kind of coordinated voice for teacher educators is an agenda topic.

The Review of Teacher Education has been in political limbo during 1998 while the other tertiary-related, and broader educational reviews are carried out. A white paper is due in later 1998. Predicting the long-term outcomes for teacher education in the current political environment is likened by Jesson (1997) to gazing into a "cloudy crystal ball". The teaching profession itself includes elements of 
support for, and resistance to new policy development. What is clearly needed are opportunities for genuine debate between policy makers, educators and the wider community about what constitutes a "good" teacher, and what institutions can do to best prepare such people for classrooms. Our children deserve nothing less.

\section{REFERENCES}

Ball, S. (1990). Politics and Policy-making: explorations in policy sociology. London: Routledge.

Bell, L. (1998). The quality of markets is not strain'd. It droppeth as the gentle rain of heaven upon the place beneath: Primary schools and the nature of the Education Market Place. Paper presented at the American Educational Research Association Annual Meeting, San Diego, April.

Codd, J. A. (1997). Knowledge, Qualifications and Higher Education: A Critical View. in M. Olssen and K. Morris Matthews, (eds.), pp. 209-227, Education Policy in New Zealand: the 1990s and beyond. Palmerston North: The Dunmore Press.

Dale, R., and Robertson, S. (1997). 'Resiting' the Nation, 'Reshaping' the State: Globalisation Effects on Education Policy in New Zealand. in M. Olssen and K. Morris Matthews, (eds.), pp. 209-227, Education Policy in New Zealand: the 1990s and beyond. Palmerston North: The Dunmore Press.

Friedman, M. (1962). Capitalism and Freedom. Chicago: University of Chicago Press. Halverson, T. J. (1996). An Examination of the Process of Educational Planning and Reform Policymaking in New Zealand During the Decade of the 1980s. Unpublished Ph.D Dissertation, University of Washington.

Harold, B. (1995). Negotiation, Contestation and Conflict: The Introduction of New Educational Policies to Three Rural Schools. Unpublished D. Phil thesis: University of Waikato.

Jesson, J. (1997). Teacher Education for Supply or Quality: Politics Problems Probabilities and Predictions, A Cloudy Crystal Ball. in M. Olssen and K. Morris Matthews, (eds.), pp. 346-357. Education Policy in New Zealand: the 1990s and beyond. Palmerston North: The Dunmore Press.

Kelly, F. (1996). Teacher education to Standards Quality Assurance- for Accountability or Improvement. Paper presented at NZCTE Annual Conference, Nelson, December.

Lauder, H. (1990). The New Right Revolution and Education in New Zealand. in S. Middleton, J. Codd and A. Jones, (eds.), pp. 1-26. New Zealand Education Policy Today. Wellington: Allen and Unwin.

McLaren, I. (1974). Education in a Small Democracy. London: Routledge \& Kegan Paul.

McQueen, H. (1996). The Politics of Pre-service Teacher Education. Paper presented at NZCTE Annual Conference, Nelson, December.

Mansell, R. Renwick, M. and Gray, A. (1997). Damned if we do and damned if we don't: dilemmas of research on contentious policy. Paper presented at NZARE Conference, Auckland, 6 December.

Ministry of Education. (1997). Quality Teachers For Quality Learning: A Review of Teacher Education. Wellington.

Partington, G. (1997). Teacher education and training in New Zealand. Auckland : Education Forum. 
Ramsay, P. (1998). The Dumbing Down of Primary Teacher Education in New Zealand. Paper presented at International Symposium on Education Reform, University of Leicester, April.

Renwick, M. and Gray, A. (1997). Compressed Programmes of Primary Teacher Education: An Initial Overview. A report prepared for the Teacher Registration Board, Te Poari Kairehita Kaiako. Wellington.

Snook, I (1996). The Education Forum and the Curriculum Framework. Delta, 48 (1), 47-56.

Snook, I. (1997). Democracy, Education and the New Right. in M. Olssen and K. Morris Matthews, (eds.), pp. 358-371. Education Policy in New Zealand: the 1990s and beyond. Palmerston North: The Dunmore Press.

Sullivan, K. (1997).They've opened Pandora's Box: Educational Reform, The New Right and Teacher's Ideologies. in M. Olssen and K. Morris Matthews, (eds.), pp. 251-282. Education Policy in New Zealand: the 1990s and beyond. Palmerston North: The Dunmore Press.

Whitty, G., Barton, L., Miles, S., Whiting, C. and Furlong, J. (1997). Making Sense of Global Reform in Initial Teacher Education. Paper presented at the American Educational Research Association Annual Conference, Chicago, 24-28 March.

Wyllie, C. (1997). 'At the Centre of the Web' : The role of the New Zealand primary school principal within a decentralised education system. Wellington: NZCER. 